\title{
PENINGKATAN KEKUATAN LENTUR PRODUK 3D PRINTING MATERIAL PETG DENGAN OPTIMASI PARAMETER PROSES MENGGUNAKAN METODE TAGUCHI
}

\author{
Eduar Iqbal Riza ${ }^{a}$ \\ ${ }^{a}$ Fakultas Teknik, Program Studi Teknik Mesin \\ Universitas Muhammadiyah Yogyakarta \\ e-mail: eduar.riza42@gmail.com \\ Cahyo Budiyantoro ${ }^{b}$ \\ ${ }^{\mathrm{b}}$ Fakultas Teknik, Program Studi Teknik Mesin \\ Universitas Muhammadiyah Yogyakarta \\ e-mail: cahyo_budi@umy.ac.id \\ Aris Widyo Nugroho ${ }^{\mathrm{c}}$ * \\ ${ }^{\mathrm{c}}$ Fakultas Teknik, Program Studi Teknik Mesin \\ Universitas Muhammadiyah Yogyakarta \\ *corresponding author, e-mail: ariswidyo.nugroho@umy.ac.id
}

\begin{abstract}
ABSTRAK
Optimasi parameter proses 3D printing dengan bahan PETG terhadap respon kekuatan lentur menggunakan metode Taguchi telah dilakukan. Penelitian ini menggunakan desain eksperimen orthogonal arrays $\mathrm{L}_{9}\left(3^{3}\right)$ dengan tiga parameter proses yang digunakan yaitu nozzle temperature, extrusion width, dan feed rate serta dengan tiga variasi level pada setiap parameter $\left(240{ }^{\circ} \mathrm{C}, 245^{\circ} \mathrm{C}\right.$, $\left.250{ }^{\circ} \mathrm{C}, 0.3 \mathrm{~mm}, 0.35 \mathrm{~mm}, 0.4 \mathrm{~mm}, 50 \%, 75 \%, 100 \%\right)$. Spesimen dipersiapkan sesuai dengan Standar ISO 178:2010 menggunakan mesin 3D printer Prusa-i3, kemudian diukur dimensi, massa, waktu produksi dan kekuatan lenturnya. Respon kekuatan lentur dianalisis menggunakan metode Taguchi melalui SN Ratio dan ANOVA untuk mendapatkan parameter optimalnya. Hasil penelitian menunjukkan bahwa parameter proses paling berpengaruh terhadap respon kekuatan lentur berturutturut adalah nozzle temperature, extrusion width dan feed rate dengan kombinasi parameter optimal yaitu nozzle temperature $\left(250{ }^{\circ} \mathrm{C}\right)$, extrusion width $(0.35 \mathrm{~mm})$, dan feed rate $(75 \%)$. Eksperimen konfirmasi menunjukkan bahwa kombinasi parameter optimal tersebut mendapatkan kekuatan lentur tertinggi dengan sebaran data yang kecil $(52,98 \pm 0,65 \mathrm{MPa})$. Selain itu, semua produk yang dihasilkan memiliki dimensi sesuai dengan standar yang digunakan.
\end{abstract}

Kata kunci: 3D printing, PETG, nozzle temperature, extrusion width, Taguchi, kekuatan lentur

\section{ABSTRACT}

Optimization of 3D printing process parameters with PETG material to the flexural strength response using The Taguchi Method has been carried out. This study used L9 $\left(3^{3}\right)$ orthogonal arrays experimental design using three process parameters, namely nozzle temperature, extrusion width, and feed rate with three levels in each parameter $\left(240^{\circ} \mathrm{C}, 245^{\circ} \mathrm{C}, 250^{\circ} \mathrm{C}, 0.3 \mathrm{~mm} 0.35 \mathrm{~mm}, 0.4 \mathrm{~mm}\right.$, $50 \%, 75 \%, 100 \%)$. Specimens were prepared according to ISO 178: 2010 Standard using a Prusai3 3D printer. Following this, their dimensions, mass, production time, and flexural strength were examined. The flexural strength response was analyzed using the Taguchi Method via SN Ratio and ANOVA analysis to obtain the optimal parameters. The results showed that the most influential process parameters on the response of flexural strength was the nozzle temperature followed by extrusion width and feed rate with an optimal combination of parameters namely nozzle temperature 
$\left(250^{\circ} \mathrm{C}\right)$, extrusion width $(0.35 \mathrm{~mm})$, and feed rate $(75 \%)$. The confirmation experiments showed that the optimal parameter combination obtained the highest flexural strength with a smaller data deviation $(52.98 \pm 0.65 \mathrm{MPa})$. In addition, all products being produced possessed dimensions in accordance with the standard.

Keywords: 3D printing, PETG, nozzle temperature, extrusion width, Taguchi, flexural strength

\section{PENDAHULUAN}

Proses rapid prototype adalah metode-metode yang digunakan untuk membuat model berskala, part satu produk, ataupun rakitan (assembly). Dalam hal proses produksinya senantiasa membentuk dan menambah maka proses ini sering disebut sebagai additive manufacturing. Beberapa sistem additive manufacturing sering digunakan di industri, antara lain: direct metal deposition (DMD), inkjet modeling (IJM), selective laser sintering (SLS), stereo-lithography (SLA) dan fused deposition modeling (FDM) [1]. Teknologi 3D printing merupakan salah satu jenis additive manufacturing dimana material disusun layer by layer dengan kontrol komputer menghasilkan struktur tiga dimensi (3D) [2]. Teknologi ini diaplikasikan di berbagai bidang meliputi: kesehatan, tekstil, otomotif, industri pesawat terbang dan bioengineering. Dengan menggunakan teknologi fused deposition modeling (FDM) untuk percetakan 3D akan mengurangi biaya produksi dan proses pumbuatan produk prototipe menjadi lebih cepat.

Salah satu bahan utama dalam proses 3D printing adalah filamen yang berfungsi sebagai bahan pengisi bentuk. Beberapa filamen yang sering digunakan pada 3D printing diantaranya adalah polylactic acid (PLA), acrylonitrile butadiene styrene (ABS), nylon, polyethylene terephthalate glycol (PETG) dan polycarbonat (PC). PETG merupakan salah satu jenis polimer yang memiliki densitas $1,38 \mathrm{~g} / \mathrm{cm}^{3}$ dan mempunyai banyak keunggulan, antara lain ketahanan terhadap kondisi cuaca, tidak rusak atau kehilangan warnanya saat terkena sinar $U V$, tidak menimbulkan bau saat proses pencetakan, memiliki sifat adhesif yang unik sehingga mampu menempel di meja pemanas dengan baik, dan memiliki faktor penyusutan termal yang rendah [3]. Polimer ini sering digunakan dalam pembuatan produk $3 \mathrm{D}$ Printing menggunakan suhu pencetakan $230^{\circ} \mathrm{C}-265^{\circ} \mathrm{C}$ dan suhu bed di atas $60^{\circ} \mathrm{C}$.

Beberapa penelitian tentang optimalisasi parameter proses 3D printing untuk meningkatkan kualitas produknya menggunakan Metode Taguchi telah banyak dilakukan. Nugroho dkk [4] mencari parameter proses optimal untuk bahan PLA dengan parameter proses yang diujikan yaitu nozzle temperature, extrusion width, infill density, dan infill pattern dengan tiga variasi level untuk setiap parameter. Infill density dan nozzle temperature menjadi parameter proses yang sangat berpengaruh terhadap respon kekuatan tarik. Sukindar, dkk [5] menambahkan bahwa parameter proses layer thickness, shell thickness, and printing speed berpengaruh terhadap respon kekuatan tarik produk dengan bahan PLA, dimana shell thickness menunjukkan parameter yang paling dominan terhadap respon kekuatan tarik. Namun dalam hal kekuatan lentur dari produk dengan bahan PLA, dari parameter proses yang digunakan yaitu layer thickness, deposition angle, dan infill pattern, terkonfirmasi bahwa layer thickness paling berpengaruh terhadap respon kekuatan lentur [6].

Szczepanik, dkk [7] melakukan perbandingan kekuatan lentur dari berbagai infill patern yaitu solid, polygonal, square dan circular dengan bahan PET. Hasil yang didapat menunjukkan kekuatan lentur berturut-turut adalah $69 \mathrm{MPa}, 33 \mathrm{MPa}, 37 \mathrm{MPa}$ dan 10,7 MPa. Peneliti lain melakukan optimalisasi parameter proses 3D printing pada bahan ABS. Parameter yang diujikan layer thickness dan printing speed dengan tiga variasi level untuk setiap parameter. Hasil penelitian menunjukkan kombinasi parameter layer thickness $0,2 \mathrm{~mm}$ dan printing speed $30 \mathrm{~mm} / \mathrm{s}$ menghasilkan beban lentur maksimal sebesar 43 N [8]. Sedangkan Szykiedans, dkk [9] meneliti sifat mekanik PETG yang dibuat menggunakan 3D printing. Penelitian membandingkan sifat PETG terbuat dari 2 bahan: PETG tanpa diperkuat dan PETG diperkuat serat kaca. Pencetakan dilakukan 
secara flat printed dan upright printed, kekuatan tarik bahan PETG dengan tambahan serat kaca sebesar $665 \mathrm{MPa}$ (flat printed), sedangkan untuk PETG tanpa penambahan serat kaca sebesar 910 MPa (upright printed). Hasil tersebut menunjukkan bahwa dengan mengatur parameter proses dapat menghasilkan produk dengan kekuatan lebih tinggi dari pada memodifikasi material. Menderes, dkk [10] melakukan penelitian mengenai pengaruh struktur pola pengisi 3D printing pada bahan PETG. Parameter yang diujikan adalah infill patern dengan variasi pola yaitu rectilinear, triangular, dan honeycomb. Hasil penelitian menunjukkan bahwa nilai kekuatan tarik maksimum sebesar 48,57 MPa terdapat pada produk dengan pola pengisi rectilinear.

Berdasarkan penelitian sebelumnya, parameter proses berupa nozzle temperature, extrusion width, infill patern dan feed rate berpengaruh terhadap kuat tarik produk 3D printing. Selain itu parameter proses layer thickness, deposition angle, orientasi, dan infill pattern berpengaruh terhadap kekuatan lenturnya. Pada penelitian ini dilakukan optimasi menggunakan kombinasi parameter proses yang berpengaruh terhadap produk 3D printing dengan bahan PETG meliputi nozzle temperature, extrusion width, dan feed rate dengan respon kekuatan lentur (flexural strength). Hasil pengujian kekuatan lentur produk dianalisis menggunakan metode Taguchi untuk mengetahui pengaruh parameter yang paling optimal serta kombinasi level optimal untuk memperbaiki kualitas produk 3D printing. Sebagai tambahan pertimbangan untuk kualitas dan produktifitas produk dilakukan pengukuran dimensi, massa produk dan waktu produksi.

\section{METODE PENELITIAN}

\subsection{Bahan dan alat}

Bahan filamen dalam penelitian ini menggunakan jenis PETG (Gambar 1) dengan diameter $1.75 \mathrm{~mm}$ dengan merk Robori dengan mesin 3D printer Prusa-i3.

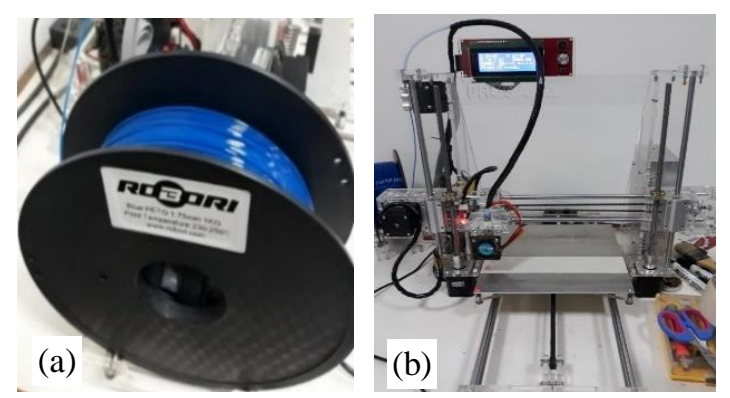

Gambar 1. (a) Filamen PETG, (b) 3D Printer Prusa I3

\subsection{Design of Experiment (DOE)}

Pembuatan desain eksperimen meliputi penentuan faktor dan level yang akan dimasukan pada konfigurasi parameter di software slic3r. Parameter yang digunakan dalam penelitian adalah nozzle temperature $\left({ }^{\circ} \mathrm{C}\right)$, extrusion width $(\mathrm{mm})$, dan feed rate $(\%)$ dengan tiga variasi level perubahan. Besarnya nilai variasi level berasal dari perhitungan secara teoritis, percobaan pra-eksperimen dan dari jurnal penelitian sebelumnya. Parameter proses dan level ditunjukkan pada Tabel 1.

Tabel 1. Parameter Proses dan Level

\begin{tabular}{ccccc}
\hline \multirow{2}{*}{ Faktor } & \multirow{2}{*}{ Parameter Proses } & \multicolumn{3}{c}{ Level } \\
\cline { 3 - 5 } & & $\mathbf{1}$ & $\mathbf{2}$ & $\mathbf{3}$ \\
\hline $\mathrm{A}$ & Nozzle Temperature $\left({ }^{\circ} \mathrm{C}\right)$ & 240 & 245 & 250 \\
$\mathrm{~B}$ & Extrusion Width $(\mathrm{mm})$ & 0,3 & 0,35 & 0,4 \\
$\mathrm{C}$ & Feed rate $(\%)$ & 50 & 75 & 100 \\
\hline
\end{tabular}


Desain faktorial menggunakan matriks ortogonal $\mathrm{L}_{9}\left(3^{3}\right)$ yang dapat diartikan bahwa penelitian dilakukan sebanyak sembilan kali percobaan dan ada tiga parameter proses serta tiga perubahan pada variabel dalam setiap faktor parameternya. Selanjutnya dilakukan duplikasi sebanyak tiga kali pada setiap faktornya.

Tabel 2. Desain Eksperimen

\begin{tabular}{cccc}
\hline \multirow{2}{*}{ Percobaan } & $\begin{array}{c}\text { Nozzle } \\
\text { Temperature } \\
\left({ }^{\circ} \mathbf{C}\right)\end{array}$ & $\begin{array}{c}\text { Extrusion } \\
\text { Width } \\
(\mathbf{m m})\end{array}$ & $\begin{array}{c}\text { Feed rate } \\
(\%)\end{array}$ \\
\hline 1 & 240 & 0,30 & 50 \\
2 & 240 & 0,35 & 75 \\
3 & 240 & 0,40 & 100 \\
4 & 245 & 0,30 & 75 \\
5 & 245 & 0,35 & 100 \\
6 & 245 & 0,40 & 52 \\
7 & 250 & 0,30 & 100 \\
8 & 250 & 0,35 & 50 \\
9 & 250 & 0,40 & 75 \\
\hline
\end{tabular}

Desain objek di gambar menggunakan software CAD secara 3 dimensi (Gambar 2.a). Dimensi objek dibuat sesuai standar spesimen uji bending untuk bahan polimer yaitu ISO 178:2010 (Gambar 2.b).
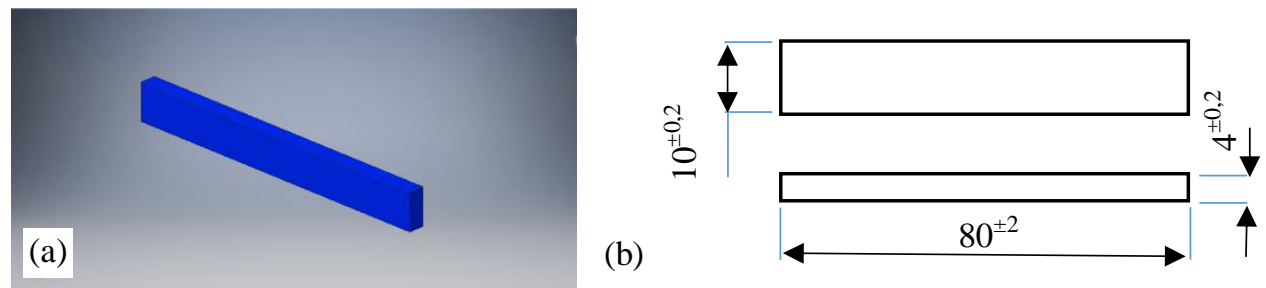

Gambar 2. (a) Desain CAD, dan (b) Dimensi Standar ISO 178:2010 dalam mm

Setelah pembuatan desain kemudian melakukan proses slicing dan setting parameter menurut DOE. Selanjutnya dilakukan proses pencetakan sebanyak 27 spesimen. Kemudian dilakukan pengambilan data pada setiap spesimen meliputi massa produk, dimensi produk, waktu produksi dan hasil pengujian lentur. Pengujian lentur menggnkan metode three point bending. Data yang telah didapat kemudian diolah dan dilakukan analisis mengunakan SNR dan ANOVA. Kriteria yang digunakan untuk respon flexural strength pada SN Ratio adalah Larger the Better (LTB) yang dihitung dengan persamaan (1).

$$
S N_{L T B}=-10 \log \left[\frac{1}{n} \sum_{i=1}^{n}\left(\frac{1}{y_{i}^{2}}\right)\right]
$$

keterangan:

$\mathrm{n}$ : jumlah pengulangan eksperimen dari suatu percobaan

$\mathrm{y}_{\mathrm{i}}$ : data pengamatan ke-i 


\section{HASIL DAN PEMBAHASAN}

Pada penelitian ini produk yang dihasilkan berjumlah 27 spesimen dengan standar ISO 178 dari sembilan percobaan dengan tiga kali replikasi setiap percobaannya yang dicetak menggunakan 3D printer prusa-i3. Kemudian dilakukan pengambilan data meliputi massa produk, dimensi produk, waktu proses pencetakan, dan pengujian lentur (Tabel 3).

Tabel 3. Data Hasil Pengukuran Dimensi, Massa, Waktu dan Kekuatan Lentur

\begin{tabular}{ccccccc}
\hline Percobaan & $\begin{array}{c}\text { Length } \\
(\mathbf{m m})\end{array}$ & $\begin{array}{c}\text { Width } \\
(\mathbf{m m})\end{array}$ & $\begin{array}{c}\text { Thickness } \\
(\mathbf{m m})\end{array}$ & $\begin{array}{c}\text { Massa } \\
(\mathbf{g r a m})\end{array}$ & $\begin{array}{c}\text { Waktu } \\
(\text { menit) }\end{array}$ & $\begin{array}{c}\text { Fluxural } \\
\text { Strength } \\
(\mathbf{M P a})\end{array}$ \\
\hline 1 & $80,21 \pm 0,02$ & $10,09 \pm 0,02$ & $3,99 \pm 0,02$ & $3,17 \pm 0,02$ & 31 & $42,59 \pm 0,05$ \\
2 & $80,19 \pm 0,02$ & $10,05 \pm 0,04$ & $4,03 \pm 0,03$ & $3,29 \pm 0,01$ & 35 & $44,27 \pm 3.23$ \\
3 & $80,09 \pm 0,02$ & $10,05 \pm 0,02$ & $4,07 \pm 0,08$ & $3,35 \pm 0,04$ & 23 & $43,51 \pm 4,79$ \\
4 & $80,12 \pm 0,03$ & $10,02 \pm 0,01$ & $3,97 \pm 0,04$ & $3,22 \pm 0,01$ & 44 & $46,93 \pm 2,25$ \\
5 & $80,17 \pm, 015$ & $10,09 \pm 0,06$ & $3,83 \pm 0,03$ & $3,25 \pm 0,01$ & 29 & $51,06 \pm 1,08$ \\
6 & $80,12 \pm 0,07$ & $10,06 \pm 0,04$ & $4,04 \pm 0,13$ & $3,38 \pm 0,01$ & 46 & $47,51 \pm 5 ., 02$ \\
7 & $80,14 \pm 0,04$ & $10,09 \pm 0,06$ & $3,96 \pm 0,10$ & $3,19 \pm 0,01$ & 33 & $46,24 \pm 4,24$ \\
8 & $80,15 \pm 0,04$ & $10,05 \pm 0,02$ & $3,96 \pm 0,03$ & $3,32 \pm 0,01$ & 52 & $51,97 \pm 1,01$ \\
9 & $80,11 \pm 0,04$ & $10,08 \pm 0,02$ & $3,93 \pm 0,02$ & $3,36 \pm 0,01$ & 32 & $52,02 \pm 1,25$ \\
\hline
\end{tabular}

Parameter feed rate dan extrusion width mempengaruhi nilai massa produk dan waktu pencetakan. Nilai feed rate yang semakin kecil dengan kombinasi extrusion width yang semakin besar akan meningkatkan massa produk, sedangkan nilai feed rate yang semakin kecil dengan kombinasi extrusion width yang semakin kecil akan membutuhkan waktu pencetakan yang semakin lama dimana pencetakkan menggunakan parameter proses feed rate terbesar yaitu dengan nilai $100 \%$ dan nilai extrusion width terbesar yaitu $0.4 \mathrm{~mm}$. Data hasil pengukuran dimensi produk dan uji lentur untuk setiap replikasi dari percobaan ditunjukkan pada Tabel 4. Hasil pengukuran dimensi: length, width, dan thickness diperoleh data dimensi dengan nilai masih dalam batas toleransi yang diizinkan sesuai standar ISO 178:2010.

Pengujian lentur dilakukan menggunakan universal testing machine (UTM). Pengujian ini dilakukan untuk mendapatkan nilai Fmax yang kemudian digunakan sebagai data perhitungan untuk mengetahui nilai kekuatan lentur (flexural strength). Metode pengujian menggunakan standar pengujian ISO 178 dengan metode three point bending (Gambar 3) dengan kecepatan pengujian sebesar $20 \mathrm{~mm} / \mathrm{menit}$.
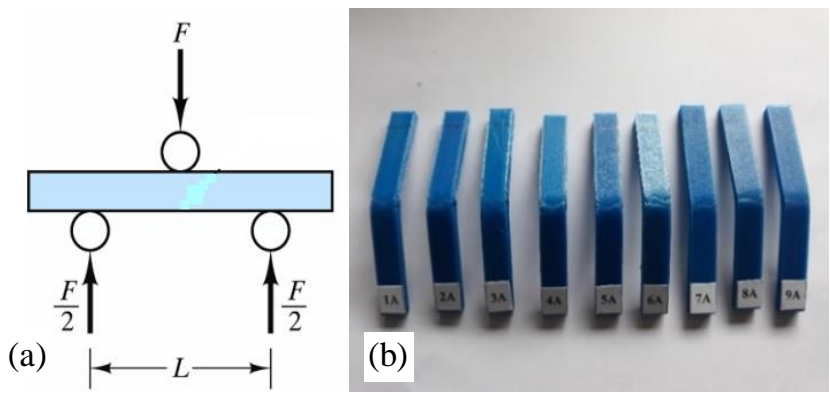

Gambar 3. (a) Skema Pengujian Three Point Bending, (b) Spesimen Hasil Uji Lentur 
Berdasarkan pengujian three oint bending, percobaan 9 menghasilkan nilai $\mathrm{F}_{\max }$ tertinggi $(85,8$ $\mathrm{N})$ sedangkan nilai $\mathrm{F}_{\max }$ terendah $(68,9 \mathrm{~N})$ dihasilkan oleh spesimen percobaan 3. Gambar 4 (a) menunjukkan kurva hasil pengujian bending pada spesimen dengan nilai $\mathrm{F}_{\max }$ terendah dan $\mathrm{F}_{\max }$ tertinggi. Permukaan sisi tarik dari specimen dengan nilai $F_{\max }$ terendah, (Gambar 4(c) tanda panah) menampilkan terdelaminasinya layer, deformasi plastis, dan rusaknya spesimen. Sedangkan pada spesimen $\mathrm{F}_{\max }$ tertinggi hanya terjadi sedikit layer yang terdelaminasi dan terdeformasi plastis (Gambar 4(b)-tanda panah). Nilai rata-rata flexural strength tertinggi (52,02 MPa) diperoleh dari percobaan 9 (Tabel 3) dengan parameter proses dan levelnya adalah nozzle temperature $\left(250^{\circ} \mathrm{C}\right)$, extrusion width $(0,4 \mathrm{~mm})$ dan feed rate $(75 \%)$.
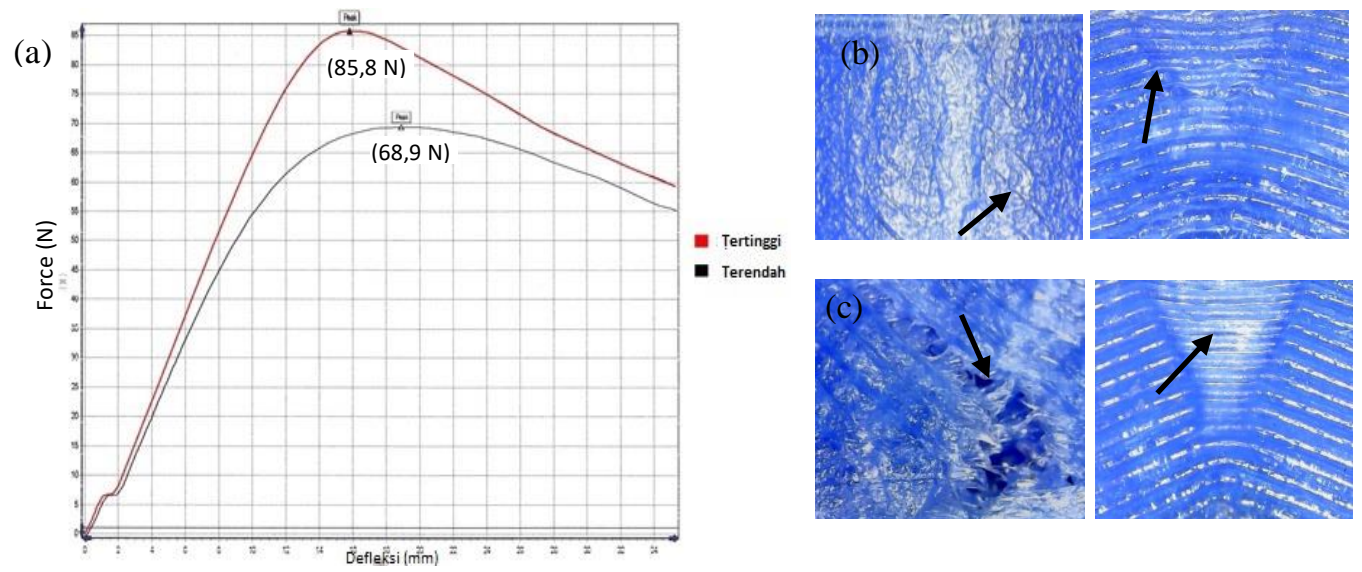

Gambar 4. (a) Hasil Pengujian Flexure Tertinggi dan Terendah, (a) Kurva BebanDefleksi, Kegagalan Spesimen dengan beban (b) Tertinggi dan (c) Terendah

Selanjutnya dilakukan analisis data, dengan terlebih dahulu melakukan pengujian residual. Pengujian ini dilakukan untuk mengetahui apakah residual memenuhi asumsi terdistribusi normal dan identik. Oleh karena itu dilakukan pengujian residual yang terdiri dari uji identik dan uji distribusi normal. Pada Gambar 5(a) dapat dilihat bahwa plot residual versus fitted values untuk residualnya tersebar secara acak/random di sekitar harga nol dan tidak membentuk pola tertentu, sehingga asumsi bersifat identik terpenuhi. Sedangkan melalui grafik probability plot of residual (Gambar 5(b)) untuk asumsi distribusi normal dapat diidentifikasi dari sebaran titik-titik pada plot tersebut membentuk pola linier atau garis lurus, sehingga residual data memenuhi asumsi distribusi normal. Setelah pengujian residual dilakukan analisis menggunakan SN Ratio dan ANOVA.
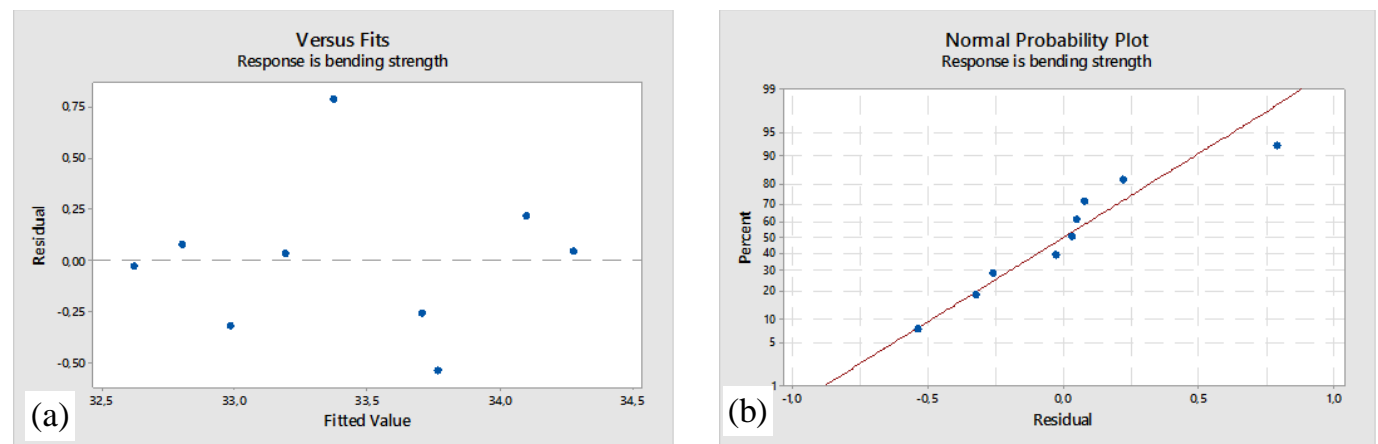

Gambar 5. Grafik : (a) Versus Fit, dan (b) Probability plot of residual, untuk Flexural Strength 


\subsection{Analisis SN Ratio}

Metode yang digunakan pada perhitungan respon flexural strength dilakukan menggunakan metode SN Ratio Larger Is Better (LTB) atau semakin besar semakin baik karena target yang dituju menentukan nilai flexural strength tertinggi dengan pemilihan level paramater dengan nilai $S N$ Ratio. Hasil perhitungan nilai SN Ratio ditampilkan dalam bentuk tabel respon (Tabel 4) dan grafik main effect plot dengan urutan yang paling berpengaruh terhadap flexural strength (Gambar 6).

Tabel 4. Respon SN Ratio pada Flexural Strength

\begin{tabular}{cccc}
\hline Level & $\begin{array}{c}\text { Nozzle } \\
\text { Temperature }\end{array}$ & $\begin{array}{c}\text { Extrusion } \\
\text { Width }\end{array}$ & $\begin{array}{c}\text { Feed } \\
\text { Rate }\end{array}$ \\
\hline 1 & 32,71 & 33,01 & 33,45 \\
2 & 33,61 & 33,78 & 33,47 \\
3 & 33,95 & 33,47 & 33,35 \\
\hline Delta & 1,24 & 0,77 & 0,13 \\
\hline Rank & 1 & 2 & 3 \\
\hline
\end{tabular}

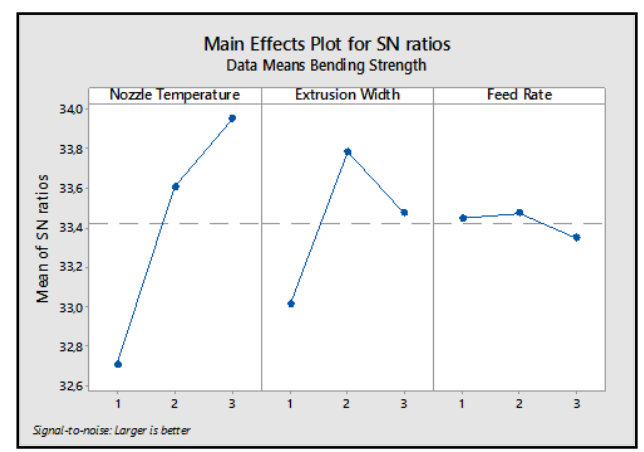

Gambar 6. Main effect plot SN Ratio Flexural Strength

Berdasarkan analisis SN Ratio dapat diketahui level yang optimal dan tingkat parameter proses yang paling berpengaruh terhadap kekuatan lentur. Gambar 6 dan Tabel 4 menunjukkan parameter proses optimal dan levelnya berdasarkan SN Ratio secara berurutan adalah nozzle temperature $\left(250^{\circ} \mathrm{C}\right)$, extrusion width $(0,35 \mathrm{~mm})$ dan feed rate $(75 \%)$. Pada percobaan 1-9 kombinasi parameter optimal tersebut belum dilakukan.

\subsection{Analisis ANOVA}

Analisis varians atau ANOVA digunakan untuk mengetahui peranan setiap parameter proses terhadap spesimen dengan melakukan pengelompokkan hasil percobaan secara statistik sesuai sumber variasi. Faktor-faktor yang termasuk dalam pengelompokkan analisis ANOVA adalah Mq, $\mathrm{Sq}_{\mathrm{A}}$ (setiap faktor), St, F-ratio, Df, Sq', p-value, dan $\rho \%$. Pada penelitian ini akan menentukan nilai critical significant atau alpha-error $\alpha$ : 0.05 (5\%). Nilai $\alpha$ : 0.05 menunjukkan penelitian ini menerima $5 \%$ kemungkinan kesalahan dalam mengklarifikasi sebagian faktor-faktor penting seperti (F-ratio) dan (P-value). Hasil analisis ditampilakan oleh Tabel 5. Tabel tersebut menunjukkan bahwa parameter yang berpengaruh significant dalam proses 3D printing dengan bahan PETG secara berurutan adalah nozzle temperature $(\mathrm{p}=0,123)$, extrusion width $(\mathrm{p}=0,266)$ dan feed rate $(\mathrm{p}=0,961)$. 
Tabel 5. Persen Kontribusi Parameter Terhadap Flexural Strength

\begin{tabular}{cccccccc}
\hline Source & Sq & Df & Mq & F-ratio & Sq' & $\mathbf{p}$ & $\boldsymbol{\rho \%}$ \\
\hline Nozzle Temperature & 69,688 & 2 & 34,8439 & 7,10 & 59,8736 & 0,123 & 55,9622 \\
Extrusion Width & 27,091 & 2 & 13,5453 & 2,76 & 17,2773 & 0,266 & 16,1486 \\
Feed Rate & 0,398 & 2 & 0,1992 & 0,04 & $-9,4150$ & 0,961 & $-8,8000$ \\
$e$ & 9,813 & 2 & 4,9066 & - & 39,2534 & - & 36,6890 \\
St & 106,990 & 8 & 106,989348 & - & - & - & 100 \\
Mean & 20082,7350 & 2 & - & - & - & - & - \\
ST & 20189,7243 & 9 & - & - & - & - & - \\
\hline
\end{tabular}

\subsection{Eksperimen Konfirmasi}

Dilakukan eksperimen konfirmasi untuk menguji kombinasi level optimal yang telah didapat dari hasil analisis SN Ratio. Eksperimen konfirmasi dilakukan pada parameter optimal berdasarkan hasil SN Ratio untuk respon nilai flexural strength.

\subsubsection{Rata-rata Prediksi dan Interval Kepercayaan}

Perhitungan rata-rata prediksi $(\mu)$ bertujuan untuk memperkirakan nilai tegangan tarik berdasarkan hasil kombinasi level optimal. Confidence interval (CI) ditentukan dengan nilai sebesar 95\% atau $\alpha$ : 0.05 yang artinya $95 \%$ dari rata-rata hasil akan berada di antara interval yang ditentukan. Berikut hasil perhitungan nilai $\mu$ dan CI.

$$
\begin{aligned}
\mu_{\text {prediksi }}-\mathrm{CI} & \leq \mu_{\text {prediksi }} \leq \mu_{\text {prediksi }}+\mathrm{CI} \ldots \ldots \ldots \ldots \ldots . . . . . . . \\
53,0274-5,5334 & \leq 53,0274 \leq 53,0274+5,5334 \\
47,494 \mathrm{MPa} & \leq 53,0274 \mathrm{MPa} \leq 58,5608 \mathrm{MPa}
\end{aligned}
$$

\subsubsection{Hasil dan Analisa Eksperimen Konfirmasi}

Tabel 6. Hasil Eksperimen Konfirmasi

\begin{tabular}{ccccccc}
\hline Replikasi & $\begin{array}{c}\boldsymbol{l} \\
(\mathbf{m m})\end{array}$ & $\boldsymbol{b}(\mathbf{m m})$ & $\begin{array}{c}\boldsymbol{h} \\
(\mathbf{m m})\end{array}$ & $\begin{array}{c}\text { Massa } \\
(\text { gram })\end{array}$ & $\begin{array}{c}\mathbf{F}_{\text {max }} \\
(\mathbf{N})\end{array}$ & $\begin{array}{c}\text { Flexural } \\
\text { Strength } \\
(\mathbf{M P a})\end{array}$ \\
\hline 1 & 80,10 & 10,1 & 4,02 & 3,31 & 90,75 & 53,2287 \\
2 & 80,60 & 10,3 & 4,00 & 3,30 & 89,69 & 52,2466 \\
3 & 80,10 & 10,4 & 3,95 & 3,32 & 86,91 & 53,4745 \\
\hline Rerata & 80,27 & 100.27 & 3,99 & 3,31 & 89,12 & 52,98 \\
\pm SD & $\pm 0,2887$ & $\pm 0,1527$ & $\pm 0,0361$ & \pm 0.0062 & $\pm 1,9832$ & $\pm 0,6497$ \\
\hline
\end{tabular}

Hasil eksperimen konfirmasi ditampilkan oleh Tabel 6. Nilai rata-rata kekuatan lentur meningkat $(52,98 \mathrm{MPa})$ dengan nilai deviasi lebih kecil $( \pm 0,65)$. Hasil ini melebihi nilai eksperimen percobaan 9 dan masuk pada jangkauan interval kepercayaan (47,49 $\mathrm{MPa} \leq 53,02 \mathrm{MPa} \leq 58,56$ $\mathrm{MPa}$ ). Optimasi parameter proses yang dilakukan menggunakan Metode Taguchi terbukti dapat meningkatkan kualitas suatu produk pada nilai kekuatan lentur dan memenuhi syarat tingkat kapercayaan $95 \%$.

Perbandingan nilai rata-rata kekuatan lenturd ari percobaan ke 9 (Tabel 3), prediksi, dan eksperimen konfirmasi disajikan pada Gambar 7. Eksperimen konfirmasi menunjukkan nilai kekuatan lentur yang lebih tinggi dari dari percobaan 9. Hasil tersebut membuktikan bahwa kombinasi eksperimen konfirmasi merupakan level parameter yang optimum untuk respon flexural strength. 


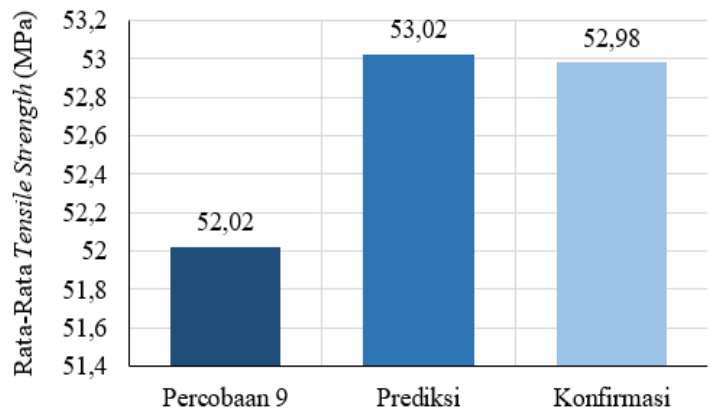

Gambar 7. Nilai flexural strength dari percobaan 9, prediksi dan pengujian konfirmasi

\section{KESIMPULAN}

Optimasi parameter proses 3D printing untuk bahan PETG dengan metode Taguchi telah berhasil dilakukan. Semua produk yang dihasilkan dengan berbagai parameter proses dan level, memiliki dimensi sesuai dengan standar. Hasil analisis SN Ratio dan Anova menunjukkan bahwa parameter proses yang berpengaruh terhadap respon flexural strength pada produk 3D printing dengan bahan PETG secara berturut-turut adalah nozzle temperature level, extrusion width dan feed rate. Eksperimen konfirmasi menunjukkan bahwa kombinasi level optimum, yaitu nozzle temperature level $3\left(250^{\circ}\right)$, extrusion width level $2(0,35 \mathrm{~mm})$, dan feed rate level $2(75 \%)$ terbukti mampu meningkatkan kualitas produk dengan memperbaiki rata-rata nilai kekuatan lentur menjadi $52,98 \pm 0,65 \mathrm{MPa}$.

\section{DAFTAR PUSTAKA}

[1] Mohamad, O. A, Masood, S.H and Bhowmik, J. L., 2015, Optimization of Fused Deposition Modeling Process Parameters: A Review of Current Research And Future Prospects. Advances in manufacturing, vol. 3, no. 1, pp. 42-53, doi: 10.1007/s40436-014-0097-7

[2] Thomas, D. J. and Claypole, T. C. , 2016, 3-D Printing. United Kingdom: Elsevier. pp. 293306.

[3] Grabowik, C., Kalinowski, K., Ćwikła, G., Paprocka, I., \& Kogut, P., 2017, Tensile tests of specimens made of selected group of the filament materials manufactured with FDM method. MATEC Web Conf. 112, 1-6.

[4] Nugroho, A.W., Mahardika,A.H., and Budiantoro, C., 2019 Improving the tensile properties of $3 D$ printed PLA by optimizing the processing parameter. JEMMME (Journal of Energy, Mechanical, Material, and Manufacturing Engineering),4(1): p. 29-36.

[5] Sukindar, N. A. B., Ariffin, M., Baharudin, B., Jaafar, C., \& Ismail, M., 2017, Analysis on the Impact Process Parameters on Tensile Strength Using 3d Printer Repetier-Host Software. ARPN Journal of Engineering and Appled Science, pp. 12, 3341-3346

[6] Lužanin, O., Movrin, D. and Plančak, M., 2014, Effect Of Layer Thickness, Deposition Angle, and Infill On Maximum Flexural Force in Fdm-Built Specimens. Serbia: University of Novi Sad, Faculty of Technical Science, 39. pp. 51-58.

[7] Szczepanik, S., and Bednarczyk, P. , 2017, Bending and Compression Properties of ABS and PET Structural Materials Printed Using FDM Technology. Poland: AGH University of 
Science and Technology Press, 1. pp. 39-42.

[8] Christiyan, K. J., Chandrasekhar, U., \& Venkateswarlu, K., 2016, A study on the influence of process parameters on the Mechanical Properties of $3 D$ printed ABS composite. IOP Conference Series. 114, 1.

[9] Szykiedans, K., Credo, W., \& Osiński, D. , 2017, Selected Mechanical Properties of PETG 3D Prints. Poland: Elsevier, 177. pp. 455-461.

[10] Menderes, K., İpekçi, A., \& Saruhan, H., 2017, Investigation of 3D Printing Filling Structures Effect on Mechanical Properties and Surface Roughness of PET-G Material Products. Turkey: Gaziosmanpasa Journal of Scientific Research, 6. pp. 114-121. 